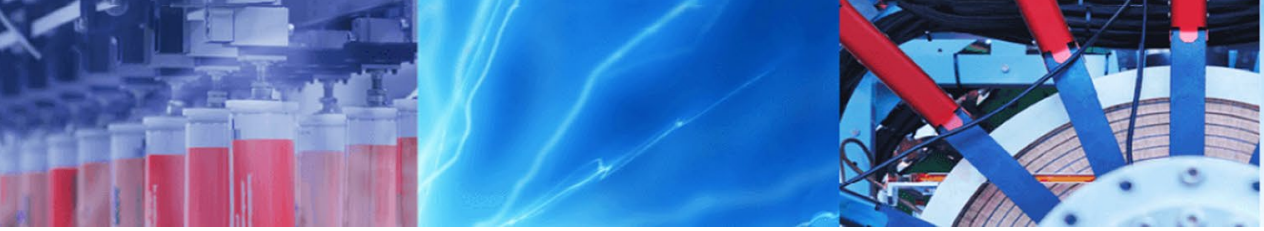

Research Article

\title{
Component element ratio analysis of the McCreedy West Fe-Ni-Cu sulfide deposit, North Range of the Sudbury igneous complex
}

\author{
Anthony E. Beswick ${ }^{1}$ (D)
}

Received: 27 August 2019 / Accepted: 21 April 2020 / Published online: 4 May 2020

(c) Springer Nature Switzerland AG 2020

\begin{abstract}
This article is motivated by the need to reveal the scientific untenability of the current, widely used, 'standard' approach to interpreting exploration borehole assay data from magmatic Ni-Cu sulfide deposits such as the McCreedy West deposit at Sudbury. This scientifically untenable methodology involves recalculating assay data to $100 \%$ sulfides, using metal tenor diagrams such as $\mathrm{Ni}_{100}$ versus $\mathrm{Cu}_{100}$ plots, and appealing to $\mathrm{R}$ factors to interpret differences between magmatic sulfide deposits from different locations. Therefore, component element ratio diagrams ( $\mathrm{Ni} / \mathrm{S}$ vs. $\mathrm{Cu} / \mathrm{S}$ ), requiring no assumptions or recalculations, are used to evaluate the fractional crystallization path of the parent sulfide melt that gave rise to the McCreedy West deposit. This methodology reveals that two compositionally distinct pyrrhotites, and sulfide-sulfide liquid immiscibility were involved in the formation of this deposit; observations previously regarded as controversial. Additionally, it allows the distribution coefficients for $\mathrm{Ni}$ and $\mathrm{Cu}$ between pyrrhotite and the parent sulfide melt to be estimated directly, and a compositional vector toward more fractionated ore to be developed. These observations are confirmed using two independent research quality data sets. It is concluded that the current, 'standard' method involving the recalculation of assay data should be rejected and that the component element ratio analysis methodology be adopted in order to correctly interpret the fractionation of magmatic sulfide deposits.
\end{abstract}

Keywords McCreedy West deposit · Sulfide fractionation · Sudbury igneous complex $\cdot$ Component element ratios

\section{Introduction}

The problems inherent in comparing assay data sets from various $\mathrm{Fe}-\mathrm{Ni}-\mathrm{Cu}$ sulphide deposits, where different recalculation procedures $[13,22,27]$ have been used, has been well expressed by Lesher and Keays [18], viz. "All recalculation methods involve assumptions regarding the locations of $\mathrm{Fe}, \mathrm{Ni}$, and $\mathrm{PGE}$ in the rock or the $\mathrm{S}$ content of the sulphide component of the rock and therefore all introduce systematic errors. As different workers have used different analytical/recalculation methods, care is required when comparing data from different studies." (Italics added for emphasis).

Furthermore, the use of R factor [7], where R is the ratio of the masses of silicate melt seen by the immiscible sulphide melt, to account for compositional differences between deposits is also invalid since they contravene both the first and second laws of thermodynamics. The first law states that the state of a systems (sulphide melt at the base of an igneous intrusion) is independent of the path by which is gets there, and the second law states that the equilibrium of that system is dependent on the intensive properties of the system such as its pressure and temperature and not on the extensive properties of the system such as the relative masses or volumes.

Similarly invalid are recalculations of assay data to $100 \%$ sulphides and the use of diagrams such as $\mathrm{Ni}_{100}$ versus $\mathrm{Cu}_{100}$ as they distort the true relationships in the data having all the same problems as Harker diagrams where the two variables involved are part of a constant sum, i.e. $100 \%$

Anthony E. Beswick, tonybeswick@xplornet.ca | 'Laurentian University, Sudbury, Canada. 
as described in detail by Chayes [8,9]. Tuominen [31], Pearce [25], Russell and Stanley [28] and papers therein.

These problems are all avoided by the use of component element ratio analysis as introduced by Beswick [4], and further developed by Beswick [5]. In the following pages, this methodology is applied to the borehole assay data set for the McCreedy West deposit which is located in the Levack Embayment on the North Range of the Sudbury igneous complex (SIC) as indicated on the sketch map shown in Fig. 1.

The deposit shows a continuous range in composition from pyrrhotite rich mineralization, typical of 'contact' deposits located along the footwall contact of the igneous complex, through to the chalcopyrite-rich mineralization which occurs as a network of veins in the brecciated footwall. The bulk assay data set used in this presentation consists of some 5700 assays having data for at least $\mathrm{Ni}, \mathrm{Cu}$, and $\mathrm{S}$ as it existed in 1997. The deposit has been described in some detail by a number of researchers $[4,11,17,23]$ to which the reader is referred for details.

For the initial compositional investigations, atomic proportion ratio diagrams are used to identify the minerals involved based on their stoichiometry [4]. For example, on an atomic ratio diagram of $\mathrm{Ni} / \mathrm{S}$ versus $\mathrm{Cu} / \mathrm{S}$, cubanite $(\mathrm{Cb})$ is located at $\mathrm{O} .33$ on the $\mathrm{Cu} / \mathrm{S}$ axis and 0.0 on the Ni/S axis, chalcopyrite $(\mathrm{Cp})$ is located at 0.5 on the $\mathrm{Cu} / \mathrm{S}$ axis and 0.0 on the $\mathrm{Ni} / \mathrm{S}$ axis, and bornite $(\mathrm{Bn})$ at 1.25 on the $\mathrm{Cu} / \mathrm{S}$ axis and 0.0 on the $\mathrm{Ni} / \mathrm{S}$. On the $\mathrm{Ni} / \mathrm{S}$ axis, millerite (MI) is located at 1.0, and a pentlandite $(\mathrm{Pn})$ with an arbitrary composition of $\left(\mathrm{Fe}_{0.5} \mathrm{Ni}_{0.5}\right)_{9} \mathrm{~S}_{8}$ would be located at $0.56((0.5 \times 9) / 8)$ on the Ni/S axis. These relationships are illustrated in Fig. 2. Together with the assay data for the McCreedy West deposit.

The difficulty with this linear scaled diagram (Fig. 2) is that the relationships amongst the low $\mathrm{Cu} / \mathrm{S}$ and low $\mathrm{Ni} / \mathrm{S}$ samples cannot be clearly evaluated. Because of this, the
Fig. 1 Sketch Map showing the general geology of the Sudbury area with the location of the McCreedy West deposit in the Levack Embayment on the North Range of the Sudbury Igneous Complex. (Modified from Ames et al. [1])

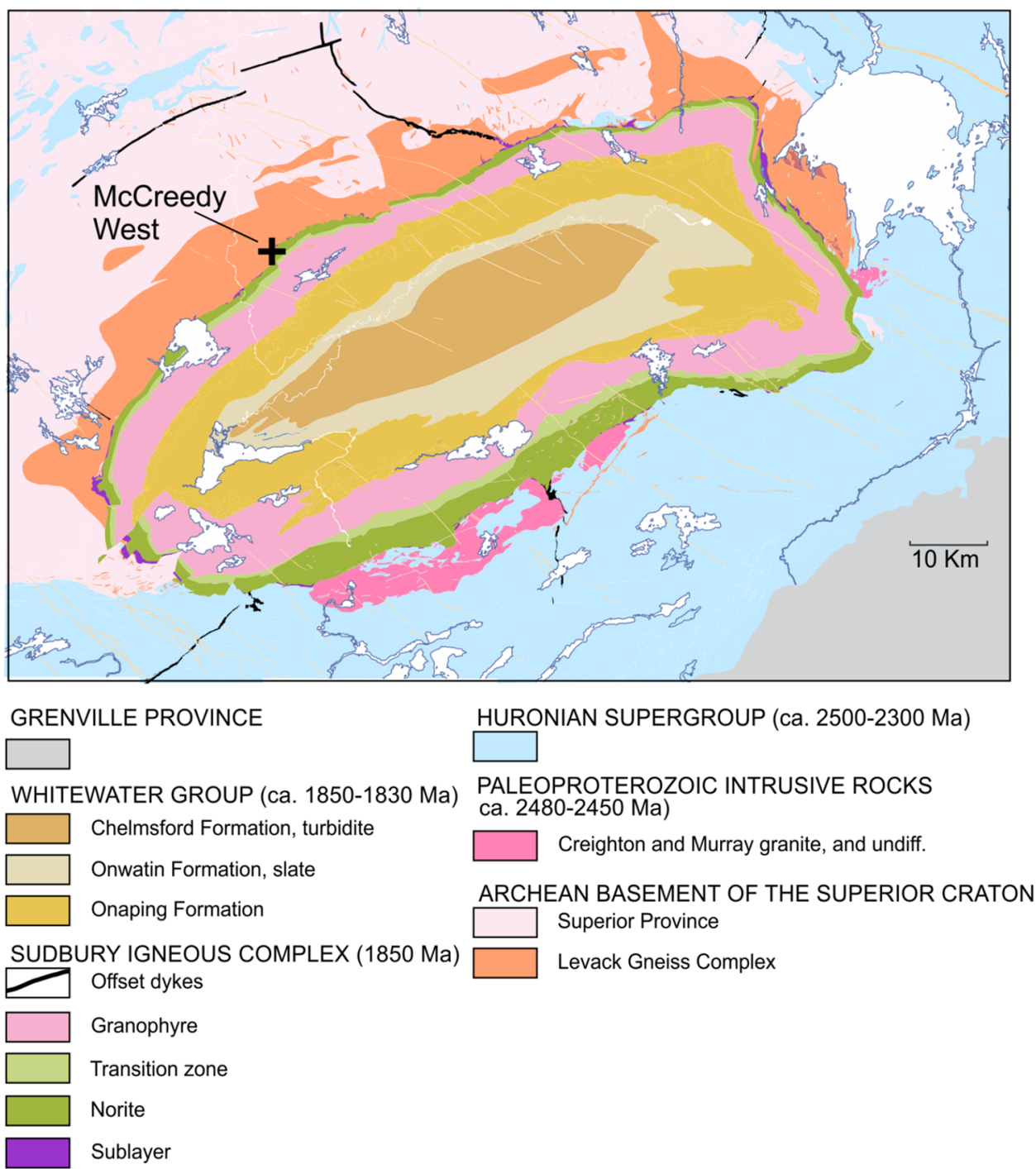




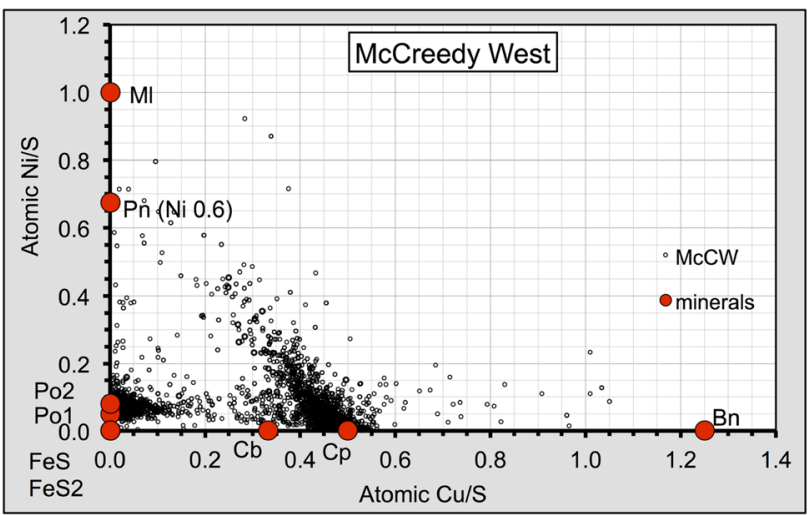

Fig. 2 A linear scaled atomic component element ratio diagram of the $\mathrm{Ni} / \mathrm{S}$ versus $\mathrm{Cu} / \mathrm{S}$ values for the borehole sample assay data for the McCreedy West deposit shown as small black circles, with the locations of the main sulfide minerals Po1 (pyrrhotite 1), Po2 (pyrrhotite 2), Cb (cubanite), Cp (chalcopyrite), Bn (bornite), Pn (pentlandite)* ${ }^{*}$, and $\mathrm{Ml}$ (millerite), shown as larger, solid red circles. *Note the pentlandite composition has arbitrarily been chosen as $\left(\mathrm{Fe}_{0.4}, \mathrm{Ni}_{0.6}\right)_{9} \mathrm{~S}_{8}$

same data are plotted on a logarithmically scaled diagram as illustrated on Fig. 3 where the relationships can be more clearly evaluated. It should be noted, however, that on such diagrams straight lines, with the exception of those having horizontal, vertical or 1:1 slopes, on a linear scaled diagram, become curved lines on a logarithmic scaled diagram.

On Fig. 3 several fractionation trends are clearly visible and in the following pages log scaled component element ratio diagrams are used to examine the distribution of $\mathrm{Cu}, \mathrm{Ni}$ and $\mathrm{S}$ between these sulfide phases in more detail.

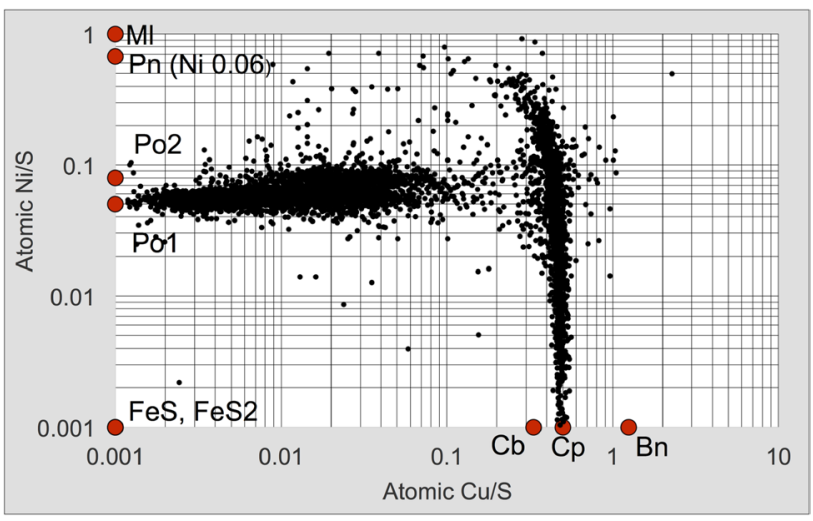

Fig. 3 A log scaled atomic component element ratio plot of the $\mathrm{Ni} / \mathrm{S}$ versus $\mathrm{Cu} / \mathrm{S}$ values for the same $\mathrm{McCreedy}$ West deposit borehole sample assays as shown in Fig. 2

\section{Fractionation of the initial sulfide melt at the McCreedy West deposit}

Figure 4 shows a log scaled, atomic component ratio diagram of $\mathrm{Ni} / \mathrm{S}$ versus $\mathrm{Cu} / \mathrm{S}$ for the $\mathrm{McCreedy}$ West assay data set with sample points sorted and colour-coded based on their wt.\% Ni contents as indicated in the legend. This diagram shows two virtually horizontal Po fractionation trends, $\mathrm{Po}_{1}$ having $2-4 \% \mathrm{Ni}$ (in blue) and $\mathrm{Po}_{2}$ having $4-6 \%$ $\mathrm{Ni}$ (in green). If the initial sulfide melt at McCreedy West contained approximately equal amounts of $\mathrm{Ni}$ and $\mathrm{Cu} \mathrm{s}$ indicated by decades of production figures and documented by Lightfoot et al. [19, p. 289] and by Lightfoot et al. [20, p. 1886], and if $\mathrm{Po}_{1}$ was the first sulfide to crystallize, as appears to be the case for Po bearing deposits such as McCreedy West, then the initial parent melt composition would plot on Fig. 4 at the point where the low $\mathrm{Ni}$ Po trend $\left(\mathrm{Po}_{1}\right.$ in blue), with an atomic Ni/S between 0.05 and 0.06 intersects a line of slope 1.0 passing through the origin, as shown by the white circle labelled $L_{p}$ on the dashed red line. Making those assumptions, the Ni/S and $\mathrm{Cu} / \mathrm{S}$ atomic ratios of this primary parental sulfide liquid would both have values between 0.05 and 0.06 .

The first low-Ni Po to crystallize from this initial sulphide liquid lies on the low-Ni $\mathrm{Po}_{1}$ trend (blue) having the lowest atomic $\mathrm{Cu} / \mathrm{S}$ of $\sim 0.0015$ and has a $\mathrm{Ni} / \mathrm{S}$ value $(\sim 0.05)$ only slightly lower than the initial sulfide liquid so that the $\mathrm{D}_{\mathrm{Ni}}$ between $\mathrm{Po}_{1}$ and liquid is only slightly less than unity $(\sim 0.91)$. This also implies a $D_{C u}$ between pyrrhotite

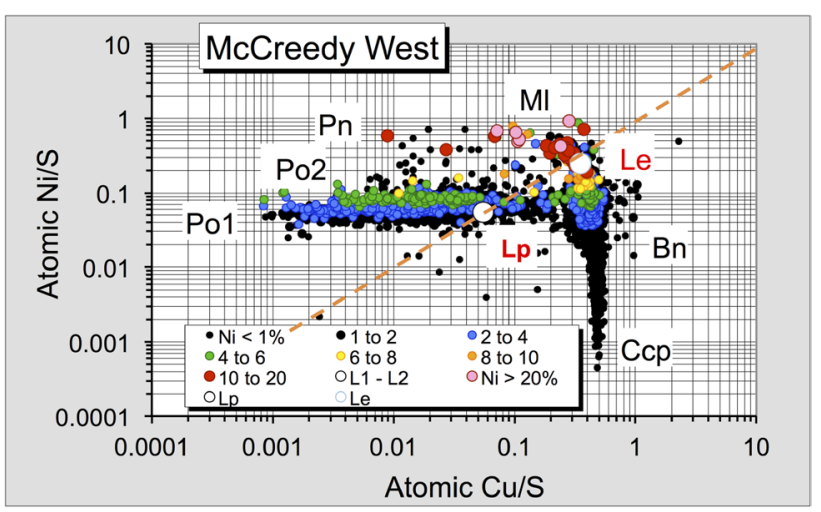

Fig. 4 A logarithmic scaled atomic $\mathrm{Ni} / \mathrm{S}$ versus $\mathrm{Cu} / \mathrm{S}$ diagram for exploration borehole assay data from the McCreedy West deposit with sample points colour-coded based on their weight percent nickel as shown in the legend. The sulfide minerals fractionating from parent liquid are labelled as Po1 (low Ni pyrrhotite), Po2, (high-Ni pyrrhotite), Pn (pentlandite), Cp (chalcopyrite), MI (millerite), and $\mathrm{Bn}$ (bornite). Along the dashed red line $\mathrm{Ni} / \mathrm{S}=\mathrm{Cu} / \mathrm{S}$. The white circle marked $L_{p}$ on that line marks the vicinity of the assumed composition of the parental sulphide liquid. The white circle labelled $L_{E}$ locates the vicinity of the suggested eutectic melt composition 
$(\mathrm{Cu} / \mathrm{S}=\sim 0.0015)$ and liquid $(\mathrm{Cu} / \mathrm{S}=\sim 0.05-0.06)$ would be between 0.03 and 0.025 , significantly lower than the experimentally determined values, e.g. 0.157-0.348 [3].

If these experimental values for $D_{C u}$ were correct this would imply that the assumed initial sulfide liquid composition was incorrect and should have a much lower $\mathrm{Cu}$ content. However, assuming the system is closed to $\mathrm{Cu}$, a low $\mathrm{Cu}$ content in the initial melt would not allow for the amount of Cu-rich footwall mineralization shown by this deposit. Alternatively, it is suggested that the experimental conditions do not adequately replicate the natural conditions that existed at McCreedy West.

Several other fractionation trends are also observed on Fig. 4 and have been labelled as $\mathrm{Po}_{1}$ (low Ni Po), $\mathrm{Po}_{2}$ (high $\mathrm{Ni} \mathrm{Po}), \mathrm{Cp}$ (chalcopyrite), Pn (pentlandite), Ml (millerite), and $\mathrm{Bn}$ (bornite). Note that there is no obvious cubanite (Cb) trend; an indication that the $\mathrm{Cb}$ in this mineralization was formed sub-solidus. It should be noted that although two pyrrhotites have not been found experimentally they have been observed by the author in several other Sudbury deposits and in the research quality data set of Naldrett et al. [23] for the McCreedy West deposit as discussed and illustrated in a subsequent section of this report. Additionally, the experimental data of Ballhaus et al. [2] found sulfide-sulfide liquid immiscibility that is the precursor to the crystallization of the high- $\mathrm{Ni} \mathrm{PO}_{2}$ as also illustrated in a subsequent section of this account.

For reasons that will become apparent below, $\mathrm{Po}_{1}$ rather than $\mathrm{Po}_{2}$ is regarded as the initial solid to crystallize from the sulfide liquid. As seen on Fig. 4, the fractional crystallization of $\mathrm{Po}_{1}$ from the initial sulfide melt causes its $\mathrm{Cu} / \mathrm{S}$ values to increases to $\sim 0.105$, while the $\mathrm{Ni} / \mathrm{S}$ remains virtually constant. Beyond this point there are very few Po samples and it is suggested that the sulfide liquid had separated into two immiscible sulfide liquids; one Cu poor and one Cu-rich $[2,4]$.

The $\mathrm{Cu}$-poor liquid $\left(\mathrm{L}_{1}\right)$, with atomic $\mathrm{Cu} / \mathrm{S}$ of $\sim 0.07$ and atomic Ni/S of $\sim 0.08$, crystallizes the high-Ni pyrrhotite $\left(\mathrm{Po}_{2}\right)$ which has an almost constant atomic Ni/S ratio of $\sim 0.08$, suggesting $D_{\mathrm{Ni}}^{\mathrm{Po} 2 / \mathrm{L}}=\sim 1.0$, and an initial $\mathrm{Cu} / \mathrm{S}$ of $\sim 0.0035$ further suggesting $D_{\mathrm{Cu}}^{\mathrm{Po} / \mathrm{L}}=0.05$. It would appear that this liquid crystallizes high $\mathrm{Ni} \mathrm{Po}\left(\mathrm{Po}_{2}\right)$ only and is then exhausted The second liquid is $\mathrm{Cu}$-rich with an atomic $\mathrm{Cu} / \mathrm{S}$ of $\sim 0.4$ and a low Ni/S of $\sim 0.015$. The $D_{\mathrm{Cu}}$ between $L_{1}$ and $L_{2}$ would then be $(\sim 0.07 / 0.4) 0.175$ and the $D_{\mathrm{Ni}}$ would be $(0.08 / 0.015) \sim 5.33$.

Following this immiscibility, and crystallization of $\mathrm{Po}_{2}$ the, Cu-rich liquid is thought to first fractionate $\mathrm{Cp}$ with an atomic $\mathrm{Cu} / \mathrm{S}=0.5$ so that the $\mathrm{D}_{\mathrm{Cu}}$ between $\mathrm{Cp}$ and the $\mathrm{Cu}$-rich liquid and would be $\sim 0.5 / 0.04=\sim 1.25$. The fractionation of $\mathrm{Cp}$ from this liquid results in a decrease in its $\mathrm{Cu} / \mathrm{S}$ value and a progressive increase in its $\mathrm{Ni} / \mathrm{S}$ value to the point where $\mathrm{Pn}$, and ultimately $\mathrm{Bn}$, and $\mathrm{Ml}$ join the fractionating assemblage. This point is interpreted to be the eutectic composition, indicated as the small white circle labelled $\mathrm{L}_{\mathrm{E}}$ on Fig. 4 , and located at $\mathrm{Ni} / \mathrm{S} \sim 0.4$ and $\mathrm{Cu} / \mathrm{S} \sim 0.2$.

Bearing in mind the Gibb's phase rule, a four component system $(\mathrm{Fe}, \mathrm{Ni}, \mathrm{Cu}, \mathrm{S})$ has six possible phases at the eutectic; (a) five solids plus a liquid or (b) four solids plus a liquid and a vapour. The two alternative assemblages, consistent with the relations observed in Fig. 4, are (a) Po, $\mathrm{Cp}, \mathrm{Pn}, \mathrm{Bn}, \mathrm{Ml}$ plus liquid (melt) or (b) $\mathrm{Cp}, \mathrm{Pn}, \mathrm{Bn}, \mathrm{Ml}$ plus liquid plus vapour. Alternative (b) is favoured as several researchers $[15,16,21,30]$ have described the occurrence of fluid inclusions in the hydrous silicates (epidote, chlorite, and actinolite) that coat the tensile fracture surfaces of the footwall and are also enriched in precious metal minerals. In this regard, it was suggested by Beswick [4], and remains the author's conviction, that the components of these minerals were transported by, and fractionally condensed from, a hydrous vapour phase that exsolved from the Cu-rich sulfide melt and immediately preceded its emplacement into the vacuum-like conditions of the tensile openings in the footwall at the time of their formation.

Finally, it is suggested that these tensile stresses also resulted in the brecciation of (1) the Po-rich mineralization as described by Pattison [24] (2) the spatially and temporally related clasts of diabase and mafic to ultramafic, cumulate textured lithologies that accompany the Po-rich mineralization in the Sublayer as described by Rae [26], Scribbins [29] and most recently by Wang et al. [32] and (3) the lower levels of the Main Mass norites described as "hanging wall breccia" on the North Range by Coats and Snajdr [10] and as "inclusion norite" on the South Range by Davis [14].

Once the fractionating phases and their fractionation paths have been identified on the atomic ratio diagram, based on their stoichiometry, one can use simple weight percent ratios diagrams that save a tedious step in the processing of large bulk assay data sets and allow ore grades and tonnages to be more directly estimated.

Since the atomic weights of the metals $(\mathrm{Ni}=59$ and $\mathrm{Cu}=64)$ are approximately twice that of sulfur $(S=32)$ the result of using weight ratios is to approximately double the atomic ratio values. It should also be noted that on these weight ratio diagrams, sample points can also be sorted and colour-coded based on the content of any element, or on any other variable characteristic (ore type, host rock type etc.), for which data are available; examples are shown below for $\mathrm{Cu}$ and $\mathrm{S}$ in Figs. 5 and 6 respectively.

In Fig. 5 both the hi-Ni and low-Ni Po trends show a similar range in $\mathrm{Cu}$ from $<1 \%$ up to $10 \%$ while most samples lying on the chalcopyrite trend have $\mathrm{Cu}>30 \%$.

Figure 6 shows an enlarged portion of the $\mathrm{Ni} / \mathrm{S}$ versus $\mathrm{Cu} / \mathrm{S}$ weight ratio diagram with sample points 


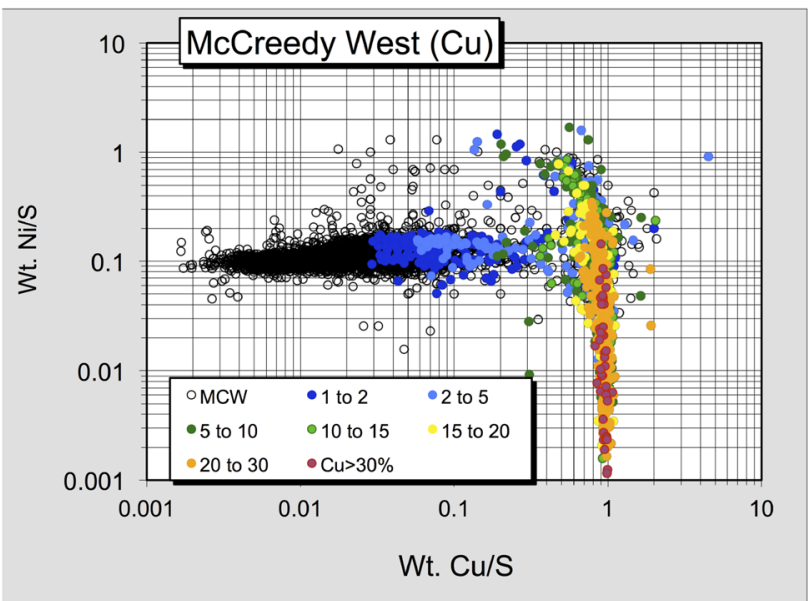

Fig. 5 A logarithmic scaled weight $\mathrm{Ni} / \mathrm{S}$ versus weight $\mathrm{Cu} / \mathrm{S}$ diagram for the assay data from the McCreedy West deposit with sample points colour-coded based on their weight percent $\mathrm{Cu}$ as shown by the legend

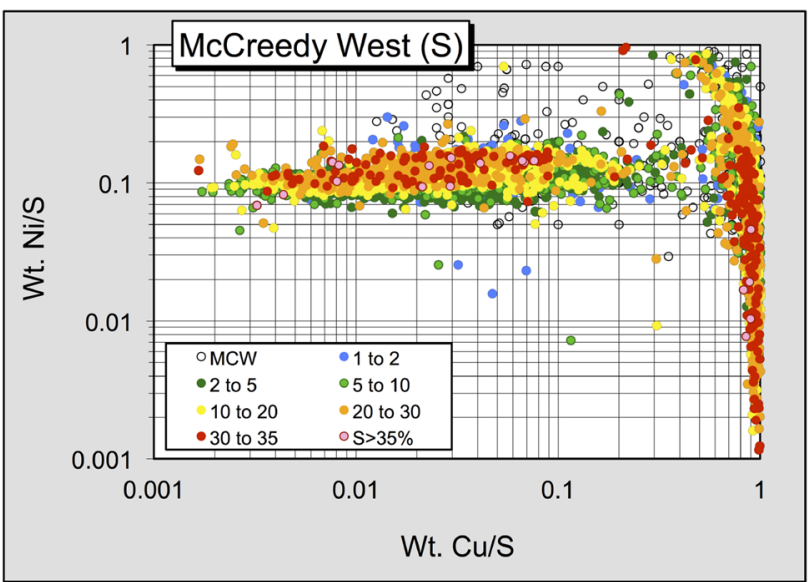

Fig. 6 An enlarged portion of the Ni/S versus $\mathrm{Cu} / \mathrm{S}$ weight ratio diagram with sample points colour-coded based on their $\mathrm{S}$ contents, as shown in the legend. This enlargement more clearly illustrates the two, distinct massive pyrrhotite trends, each having $S>30 \%$., in addition to the massive chalcopyrite fraction trend

colour-coded based on their $\mathrm{S}$ contents. This enlargement clearly shows the separation between the two subparallel massive Po trends, both of which have $\mathrm{S}>30 \%$. Note the paucity of samples and the complete lack of massive sulphide compositions between $\mathrm{Cu} / \mathrm{S}$ weight ratios of $\sim 0.1$ and $\sim 0.8$, which is interpreted as the immiscibility gap first identified at McCreedy West by Beswick [4]. It also seems clear from Fig. 6 that the somewhat diffuse nature of the two horizontal Po trends is due to a 'halo' of disseminated, low-S mineralization $(\mathrm{S}<5 \%)$ mantling each of the two trends displayed by the massive sulfide $(\mathrm{S}>30 \%)$ mineralization.
Of particular notice on Fig. 6 are the slight increases in the $\mathrm{Ni} / \mathrm{S}$ values of both massive Po trends $(\mathrm{S}>30 \%$ ) as $\mathrm{Cu} / \mathrm{S}$ increases. This is consistent with a progressive decrease in the $\mathrm{S}$ content of both these massive Po trends as their $\mathrm{Cu}$ contents increase, and their $\mathrm{Ni}$ contents remain virtually constant as seen in Fig. 4.

\section{Further evidence of sulfide-sulfide liquid immiscibility}

The suggestion of liquid immiscibility within the $\mathrm{Fe}-\mathrm{Ni}-\mathrm{Cu}-\mathrm{S}$ system, which covers the compositions of the major sulfide minerals in magmatic sulfide mineralization, has been questioned by Brenan et al. [6] despite the experimental results of Ballhaus et al. [2] and the suggestion of Beswick [4] that sulfide liquid immiscibility had occurred at the McCreedy West deposit.

On Fig. 7 a log-scaled component ratio diagram of atomic $\mathrm{Ni} / \mathrm{S}$ versus atomic $\mathrm{Cu} / \mathrm{S}$ for the McCreedy West data set is overlain with the experimental results of Ballhaus et al. [2] who identified immiscibility over the temperature range of $900-1275^{\circ} \mathrm{C}$ for two different starting compositions, mixes 8 and 11 , shown as black and white triangles respectively on Fig. 7. In this temperature range, mix 11 produces an exsolved Cu-enriched melt (shown in red) in a Cu-depleted host matrix melt (shown in blue), and for mix 8 the exsolved, more Cu-rich melt is shown in yellow and the less $\mathrm{Cu}$-rich matrix melt in green. On this diagram, it is clear that the experimental data of Ballhaus et al. [2] are in good agreement with the immiscibility gap seen in the McCreedy West assay data.

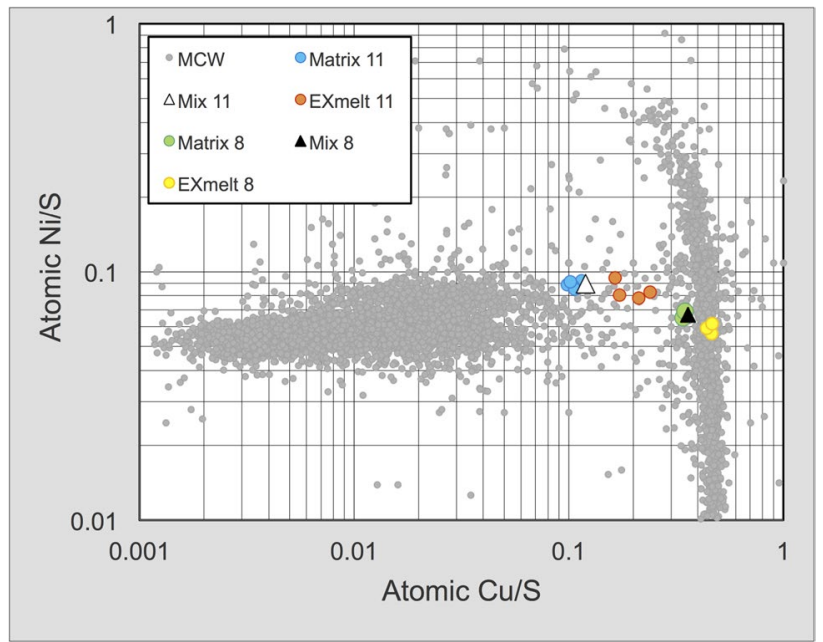

Fig. 7 An enlarged portion of the log scaled component element atomic ratio diagram of $\mathrm{Ni} / \mathrm{S}$ versus $\mathrm{Cu} / \mathrm{S}$ for the $\mathrm{McCreedy}$ West deposit (grey) overlain with the experimental data of [2] 
More recently, additional evidence of sulfide liquid immiscibility has also been found on the $(\mathrm{Ni}+\mathrm{Cu}) / \mathrm{S}$ versus $(\mathrm{Ni}+\mathrm{Cu}+\mathrm{S}) \%$ diagram for the McCreedy West deposit [5], as illustrated in Fig. 8. On this diagram, the initial massive Po mineralization, having the lowest $(\mathrm{Ni}+\mathrm{Cu}) / \mathrm{S}$ values, has $\sim 40 \%(\mathrm{Ni}+\mathrm{Cu}+\mathrm{S})$ so that the $\mathrm{Fe}$ content of this massive Po mineralization must be $\sim 60 \%$. It is also apparent, as $(\mathrm{Ni}+\mathrm{Cu}) / \mathrm{S}$ increases in the most massive mineralization, that the Fe content decreases progressively. Most notable of all are the two distinct, sub-horizontal 'bands' of massive $(\mathrm{Ni}+\mathrm{Cu}+\mathrm{S} \geq 40 \%)$ to highly disseminated $(\mathrm{Ni}+\mathrm{Cu}+\mathrm{S} \leq 1 \%)$ mineralization, and the clear absence of mineralization between them. It is suggested that this compositional gap is further clear evidence of immiscibility between $\mathrm{Cu}$-poor and $\mathrm{Cu}$-rich sulphide liquids.

Further evidence, supportive of liquid immiscibility in the $\mathrm{Fe}-\mathrm{Ni}-\mathrm{Cu}-\mathrm{S}$ system, is also provided by an entirely separate, smaller, research quality, data set for the McCreedy West deposit; that of Naldrett et al. [23], as illustrated in Fig. 9. On this diagram, two distinctly separate Po trends are clearly visible once again. Most of the low-Ni Po samples contain 2-3\% Ni while the high-Ni Po samples have up to $5 \% \mathrm{Ni}$ or more. The miscibility gap between the Po-rich and $\mathrm{Cp}$-rich mineralization is also apparent, there being only three sample bridging this gap. It is also apparent that highly fractionated $\mathrm{Bn}$ and Ml bearing mineralization is absent from this data set.

In view of the evidence presented by Figs. 4, 5 and 6 , it seems undeniable that sulfide liquid immiscibility has occurred at some, possibly all, Fe-Ni-Cu-PGE sulfide deposits associated with the SIC, to produce $\mathrm{Cu}$-poor and $\mathrm{Cu}$-rich sulfide mineralization.

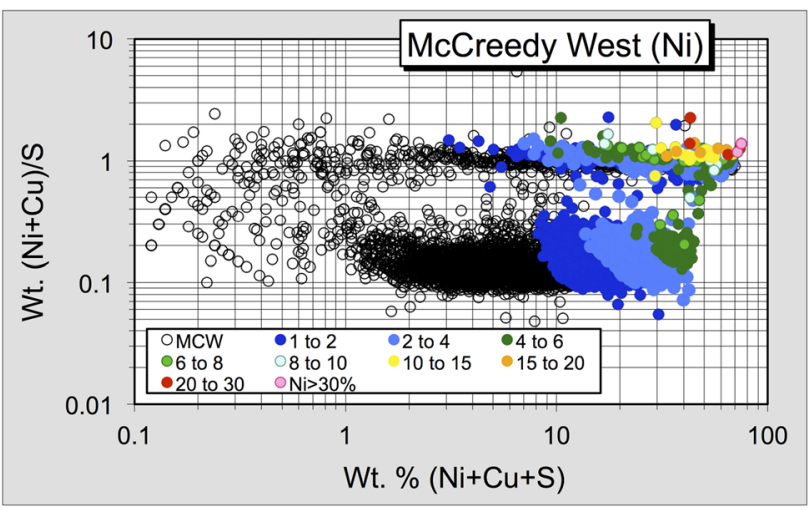

Fig. 8 A plot of the wt. ratio of $(\mathrm{Ni}+\mathrm{Cu}) / \mathrm{S}$ versus the wt.\% $(\mathrm{Ni}+\mathrm{Cu}+\mathrm{S})$. Note the two subhorizontal 'bands' of data points ranging from massive $(>40 \% \mathrm{Ni}+\mathrm{Cu}+\mathrm{S})$ to highly disseminated $(<1 \%)$ and the immiscibility gap between them

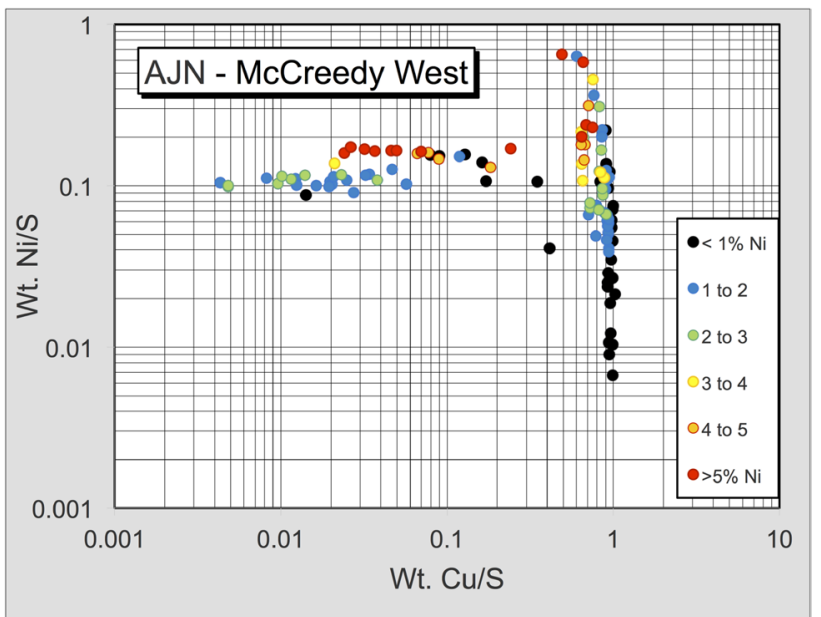

Fig. 9 The $\mathrm{Ni} / \mathrm{S}$ versus $\mathrm{Cu} / \mathrm{S}$ diagram for a research data set of Naldrett et al. [23] for the McCreedy West deposit with sample points colour-coded based on their $\mathrm{Ni} \%$ values as indicated in the legend. Note the presence of low-Ni Po and high-Ni Po trends and the separation between Cu-poor and Cu-rich mineralization: both an indication of sulfide liquid immiscibility

\section{A vector towards more fractionated mineralization}

Through the course of this research it has been observed that the $(\mathrm{Ni}+\mathrm{Cu}) / \mathrm{S}$ ratio values generally increase as fractionation progresses from low-Ni Po through to the $\mathrm{Bn}+\mathrm{Ml}$ bearing assemblages as seen in Fig. 10 where the sample points are colour-coded based on their value for this ratio.

This observation indicates that the $(\mathrm{Ni}+\mathrm{Cu}) / \mathrm{S}$ value can be used as a vector toward more fractionated, and more precious metal (PPGE) enriched, mineralization. Figures 11, 12 and 13, show three perpendicular

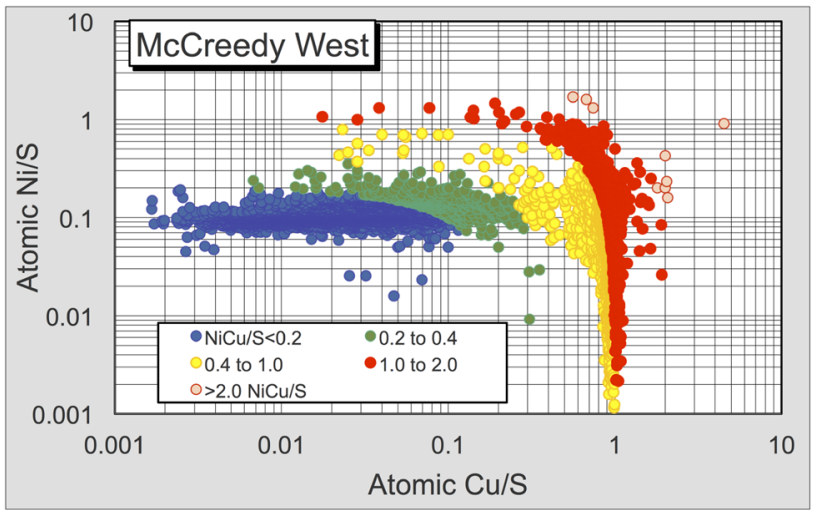

Fig. 10 Atomic Ni/S versus $\mathrm{Cu} / \mathrm{S}$ diagram for the McCreedy West deposit with sample points colour-coded based on their $(\mathrm{Ni}+\mathrm{Cu}) / \mathrm{S} \%$ value, as indicated in the legend, which is seen to increase with progressive fractionation 


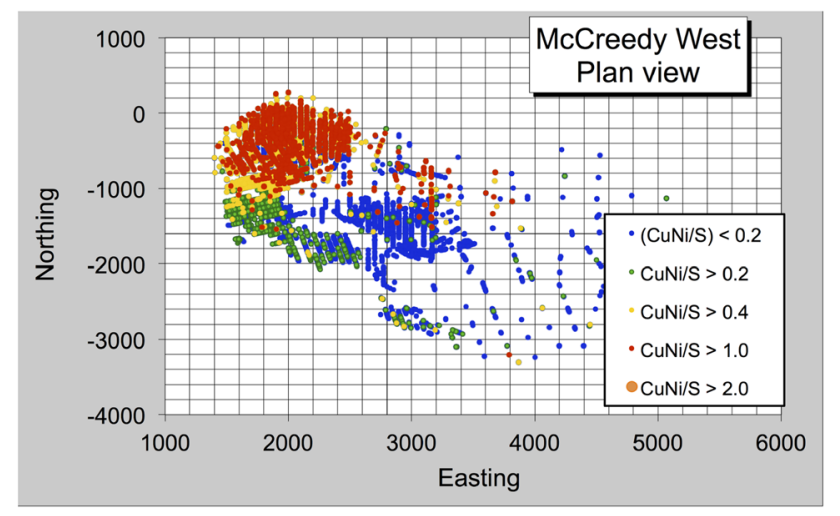

Fig. 11 A plan view perspective on the spatial distribution of drill hole samples from the McCreedy West deposit which are colourcoded based of their $(\mathrm{Ni}+\mathrm{Cu}) / \mathrm{S}$ values as indicated in the legend

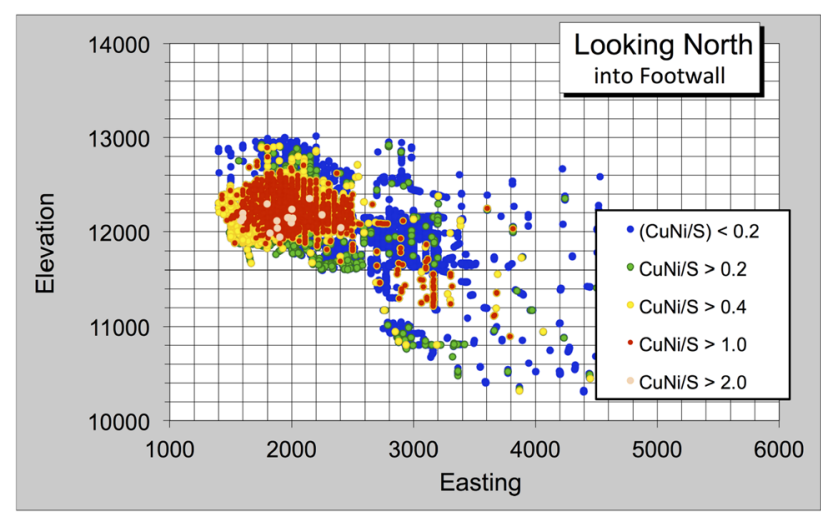

Fig. 12 A perspective looking north into the footwall on the spatial distribution of drillhole samples from the McCreedy West deposit with colour coding the same as in Fig. 11

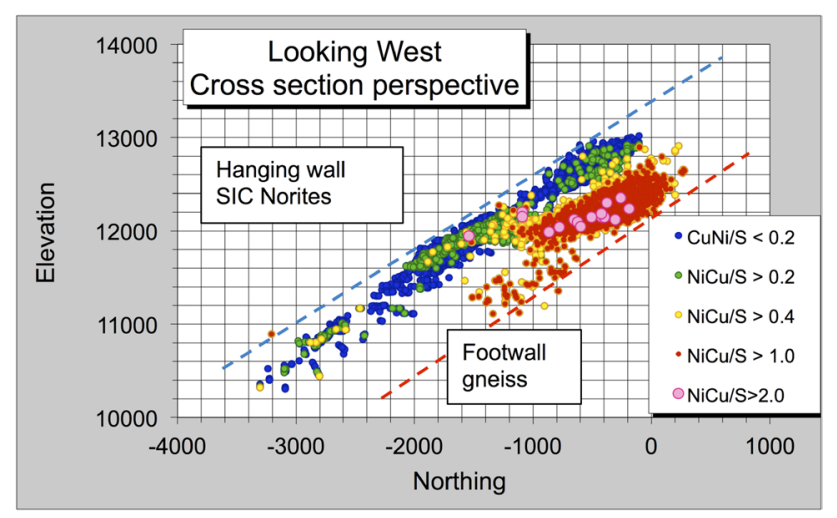

Fig. 13 A cross sectional perspective looking west on the spatial distribution of drill hole samples from the McCreedy West deposit with colour-coding the same as in Figs. 11 and 12. The two parallel dotted lines enclosing the deposit are approximately 1400 feet apart projections of the spatial relationships of the McCreedy West deposit; a plan view, a projection looking north into the footwall, and a cross-sectional view looking west, respectively. In each case one sees a progressive, continuous increase in $(\mathrm{Ni}+\mathrm{Cu}) / \mathrm{S}$ as indicated by the colours shown in their legends.

In Fig. 13 it can be seen that the Cu-rich footwall mineralization forms two arcuate, concave upward zones which curve in opposite directions both having a maximum depth well over $1000 \mathrm{ft}$. below the footwall contact. The Po-rich mineralization, in contrast, is restricted along the footwall contact of the SIC within the Archean gneisses. On Fig. 13 it is also seen, above the centres of the two footwall mineralization lobes, that the upper surface of the contact mineralization shows small upward swells. Bearing in mind that the footwall mineralization occupies tensional opening in the footwall this observation supports the suggestion [4] that the footwall was uplifted after Po cumulates had formed along the contact. This suggestion is also consistent with the fact that the Po rich mineralization is frequently brecciated [24] as are the hanging wall norites [10] and the cumulate textured ultramafic inclusions in the Sublayer [32] that have the same age (within the range of analytical error) as the SIC and the mineralization [12]. It appears therefore that the timing of the brecciation is post emplacement of the SIC, post silicate-sulfide liquid immiscibility, post settling, accumulation and pooling of sulfide liquid in topographic lows along the footwall contact, as well as post solidification of the lower levels of the norite and post Po crystallization and solidification.

\section{Summary and conclusions}

It has been demonstrated, using component element ratios of bulk assay data sets for exploration boreholes at the McCreedy West deposit, such as weight ratios of $\mathrm{Ni} / \mathrm{S}$ versus $\mathrm{Cu} / \mathrm{S}$ and $(\mathrm{Ni}+\mathrm{Cu}) / \mathrm{S}$ versus $(\mathrm{Ni}+\mathrm{Cu}+\mathrm{S}) \%$, it is possible to:-

(a) Identify the fractionation path and composition of the parental sulfide liquid.

(b) Determine the composition of the primary Po, prior to the subsequent exsolution of $\mathrm{Pn}$ and $\mathrm{Cp}$.

(c) Estimate the distribution coefficient values between Po and sulfide liquid for $\mathrm{Ni}$ and $\mathrm{Cu}$ and potentially any other element for which assay data are available.

(d) Develop a measure of the extent of fractionation displayed by any sample(s) in the data set, and which can also be employed as a vector toward more, or less, fractionated mineralization. 
It should be abundantly clear that the capabilities of the component element ratio methodology is superior to the current 'standard approach' of recalculating the values to $100 \%$ sulfides, plotting diagrams such as $\mathrm{Ni}_{100}$ versus $\mathrm{Cu}_{100}$, and using $\mathrm{R}$ factors to explain compositional differences between deposits.

Finally, in light of the above capabilities, it is recommended that the results of studies that have used the 'standard approach' be reevaluated using the component element ratio methodology.

Acknowledgements The author is indebted to Doug Morrison, Director of the Center for Excellence in Mining Innovation (CEMI) for ongoing support during the writing and the publication of this research. Without access to the massive MEBS data base of Vale (formerly Inco Ltd.), which includes assay data for a large number of deposits around the Sudbury Basin, it would not have been possible to carry out the research investigations that underpin this communication. The author continues to be particularly indebted to Dr. Larry Cochrane, former Director of Mines Exploration, at Inco Ltd. for many early discussions on the deposits of the SIC. The author is also grateful for the many discussions and constructive comments of Frank Brunton, and for the comments of Richard James and Doug Tinkham, colleagues in Sudbury. Last but by no means least I thank Julie Chartrand for her able assistance formatting diagrams and text in conformity with publication requirements.

\section{Compliance with ethical standards}

Conflict of interest The authors declare that they have no conflict of interest.

\section{References}

1. Ames DE, Davidson A, Buckle JL, Card KD (2005) Geology, Sudbury bedrock compilation, Ontario. Geological Survey of Canada, Open File 4570, scale 1:50 000

2. Ballhaus C, Tredoux M, Spath A (2001) Phase Relations in the $\mathrm{Fe}-\mathrm{Ni}-\mathrm{Cu}-\mathrm{PGE}-\mathrm{S}$ system at magmatic temperature and application to massive sulphide ores of the Sudbury igneous complex. J Petrol 42(10):1911-1926

3. Barnes SJ, Zientek ML, Severson MJ (1997) Ni, Cu, Au and platinum-group element contents of sulphides associated with intraplate magmatism: a synthesis. Can J Earth Sci 34:337-351

4. Beswick $A E$ (2002) An analysis of compositional variations and spatial relationships within $\mathrm{Fe}-\mathrm{Ni}-\mathrm{Cu}$ sulfide deposits on the North Range of the Sudbury igneous complex. Econ Geol 97:1487-1508

5. Beswick AE (2013) Some applications of element ratio analysis to understanding the compositional variations displayed by a selection of Fe-Ni-Cu-PGE sulphide deposits at Sudbury, Ontario, Canada. In: Mineral deposit studies group 35th annual winter meeting. programme and abstract volume, $\mathrm{p} 27$

6. Brenan JM, Haider N, Andrews D (2008) Experimental evaluation of liquid immiscibility in a portion of the system Fe$\mathrm{Ni}-\mathrm{Cu}-\mathrm{S}$ using high gravitational acceleration. Econ Geol 103(7):1563-1570

7. Campbell IH, Naldrett AJ (1979) The influence of silicate-sulfide ratios on the geochemistry of magmatic sulfides. Econ Geol 74:1503-1506
8. Chayes $F(1949)$ On ratio correlation in geology. J Geol 52:239-254

9. Chayes F (1971) Ratio correlation. University of Chicago Press, Chicago, $p 99$

10. Coats CJA, Snajdr P (1984) Ore deposits of the North Range. Onaping-Levack area, Sudbury. In: Pye EG, Naldrett AJ, Giblin PE (eds) The geology and ore deposits of the Sudbury structure. Ontario geological survey special volume 1, chapter 14

11. Constantin $M$, Lesher $C M$, Beswick $A E$, Davis $C$, Farrow $C$, Tavchandjian O (1999) 3D Ni-Cu-PGE distributions at the McCreedy West deposit and implications for ore genesis in the Sudbury North Range. In: Joint annual meeting of the geological and mineralogical associations of Canada, abstracts, vol 24, pp 24-25

12. Corfu F, Lightfoot PC (1996) U-Pb geochronology of the Sublayer environment, Sudbury igneous complex, Ontario. Econ Geol 91(7):1263-1269

13. Cowden A, Woolrich P (1987) Geochemistry of the Kambalda iron-nickel sulfides: implications for models of sulfide-silicate partitioning. Can Miner 25:21-36

14. Davis GC (1984) Little stobie mine: a South Range contact deposit. In: Pye EG, Naldrett AJ, Giblin PE (eds) The geology and ore deposits of the Sudbury structure. Ontario geological survey special volume 1, pp 361-370

15. Farrow CEG, Watkinson DH (1992) Alteration and the role of fluids in $\mathrm{Ni}$, Cu and platinum-group element deposition, Sudbury Igneous Complex contact, Onaping-Levack area, Ontario. Miner Petrol 46:67-83

16. Hanley JJ, Mungall JE (2003) Chlorine enrichment and hydrous alteration of the Sudbury breccia hosting footwall $\mathrm{Cu}-\mathrm{Ni}-\mathrm{PGE}$ mineralization at the Fraser Mine, Sudbury, Ontario, Canada. Can Miner 41(4):857-881

17. Hoffman EL, Naldrett AJ, Alcock RA, Hancock RGV (1979) The noble-metal content of ore in the Levack West and Little Stobie mines, Ontario. In: Naldrett AJ (ed) Nickel-sulfide and platinum-group-element deposits. Can Miner 17:437-451

18. Lesher M, Keays RR (2002) Komatiite-associated Ni-Cu-(PGE) deposits: geology, mineralogy, geochemistry, and genesis. In: Cabri LJ (ed) The geology, geochemistry, mineralogy and mineral beneficiation of platinum-group elements. Canadian Institute of Mining, Metallurgy and Petroleum, Special Volume 54, pp 579-618

19. Lightfoot PC, Keays RR, Morrison GG, Bite A, Farrell K (1997) Geochemical Relationships in the Sudbury igneous complex: origin of the main mass and offset dikes. Econ Geol 92:289-307

20. Lightfoot PC, Keays RR, Doherty W (2001) Chemical evolution and origin of nickel sulfide mineralization in the Sudbury igneous complex, Ontario, Canada. Econ Geol 96:1855-1875

21. Maclnnis $L$ (2018) Constraining alteration in the footwall of the Sudbury igneous complex: a case study of the alteration footprint of the Podolsky, Cu-(Ni)-PGE deposit, Sudbury. M.Sc. in Geology, Laurentian University

22. Naldrett AJ, Hoffman AH, Chen-Lin Chou, Naldrett SR (1979) The composition of $\mathrm{Ni}$ sulfide ores, with particular reference to their content of PGE and Au. Can Miner 17:403-415

23. Naldrett AJ, Asif M, Schandl E, Searcy T, Morrison GG, Binney WP, Moore C (1999) Platinum-group elements in the Sudbury ores: significance with respect to the origin of different ore zones and to the exploration for footwall ores. Econ Geol 94:185-210

24. Pattison EF (1979) The Sudbury Sublayer. Can Miner 17:257-274

25. Pearce TH (1968) A contribution to the theory of variation diagrams. Contrib Miner Petrol 19:142-157

26. Rae DR (1975) Inclusions in the sublayer from Strathcona Mine, Sudbury, and their significance. Unpubl. Ph.D. thesis, University of Toronto 
27. Ross JR, Keays PR (1979) Precious metals in volcanic-type nickel sulfide deposits. Relationship with the composition of the ores and their host rocks. Can Miner 17:417-435

28. Russell JK, Stanley CR (1990) Theory and application of Pearce element ratios to geochemical data analysis. Geological Association of Canada, Short Course vol \#8, $315 \mathrm{p}$

29. Scribbins BT (1978) Exotic inclusions from the South Range sublayer, Sudbury. Unpubl. M.Sc. thesis, University of Toronto)

30. Tuba G, Molnár F, Ames DE, Péntek A, Watkinson DH, Jones PC (2014) Multi-stage hydrothermal processes involved in "low-sulfide" $\mathrm{Cu}(-\mathrm{Ni})-\mathrm{PGE}$ mineralization in the footwall of the Sudbury Igneous Complex (Canada): amy Lake PGE zone, East Range. Miner Depos 49:7-47
31. Tuominen HV (1964) The trends of differentiation in percentage diagrams. J. Geol. 72:855-860

32. Wang Y, Lesher CM, Lightfoot PC, Pattison EF, Golightly JP (2018) Shock metamorphic features in mafic and ultramafic inclusions in the Sudbury igneous complex: implications for their origin and impact excavation. Geol Soc Am 46(5):443-446

Publisher's Note Springer Nature remains neutral with regard to jurisdictional claims in published maps and institutional affiliations. 